\title{
Southernmost limit of the Vicugna vicugna Molina (Mammalia: Camelidae) in Chile: a review of old records and new field data
}

\section{Límite sur de la distribución de Vicugna vicugna Molina (Mammalia: Camelidae) en Chile: una revisión de los registros antiguos y nuevos datos de campo}

\author{
Yerko A. Vilina ${ }^{1 *}$, Franco Cruz-Jofré $E^{1,2} \&$ Valeria Saba $J^{3}$ \\ ${ }^{1}$ Escuela de Medicina Veterinaria. Facultad de Medicina Veterinaria y Recursos Naturales. Universidad Santo Tomás, Santiago, \\ Chile. \\ ${ }^{2}$ Laboratorio de Genética y Evolución, Facultad de Ciencias, Universidad de Chile. Santiago, Chile. \\ ${ }^{3}$ Instituto de Ciencias Biomédicas, Facultad de Medicina, Universidad de Chile. Santiago, Chile. \\ *yvilina@santotomas.cl
}

\begin{abstract}
Vicugna vicugna Molina is a mammal of relatively large size and conspicuous habits; nevertheless, its southernmost distribution limit in Chile is not well established. Many authors were fixed this limit at $27^{\circ} 30^{\prime} \mathrm{S}$, we deliver field information of a distribution limit $140 \mathrm{~km}$ further south to the recently proposed.
\end{abstract}

KeYwords: Vicugna vicugna vicugna, V. vicugna mensalis, Andean steppe, Argentina, Chile.

\begin{abstract}
RESUMEN
Vicugna vicugna Molina es un mamífero de tamaño relativamente grande y de hábitos conspicuos; sin embargo, su límite de distribución Sur en Chile no está bien establecido. Muchos autores han fijado este límite a los $27^{\circ} 30^{\text {'S }}$, nosotros entregamos información de campo de un límite de distribución $140 \mathrm{~km}$ más al sur al propuesto recientemente.
\end{abstract}

Palabras Claves: Vicugna vicugna vicugna, V. vicugna mensalis, Estepa Andina, Argentina, Chile.

The vicuña (Vicugna vicugna Molina 1782) is a endemic mammal of the Altiplano, however by the end of the Pleistocene it had inhabited a wide range of distribution, reaching Patagonia in the extreme south of the continent (Weinstock et al. 2009).

Osgood (1943) explains that when describing the species in 1782, Molina mentions that the vicuña would be common in the Provinces of Copiapo and Coquimbo, though he declares that this data was obtained from local observers. In Chile it would be distributed in the Andes mountain range, from the limit with Bolivia and Peru, to the region of Atacama, between 18 $45^{\prime} \mathrm{S}$ and $27^{\circ} 30^{\prime} \mathrm{S}$ (Galaz 1998). The southern limit was established at the Negro Francisco lagoon $\left(27^{\circ} 30^{\prime} \mathrm{S}\right)$ by Glade \& Cunnazza (1992), it has been ratified by Gonzalez et al. (2000), Iriarte (2008) and again by Gonzalez et al. (2009). More recently Valladares (2012) reafirm the limit on Nevado Tres Cruces National Park (Negro Francisco lagoon).
Two subspecies have been recognized, Vicugna vicugna vicugna Molina 1782, and Vicugna vicugna mensalis Thomas 1917 (Franklin 1982; Wheeler 1991). In Chile, the number of $V$. vicugna mensalis would border 20,000 individuals in the Region of Arica-Parinacota, which represents approximately the $97 \%$ of the total number of vicuña that live in the country, whereas the subspecies $V$. vicugna vicugna would inhabit the southern sector of its area of distribution range, mainly in the regions of Antofagasta and Atacama, and where the other $3 \%$ of the population would be found (Galaz 2005).

In Argentina, its southern distribution limit would be at $29^{\circ} 30^{\prime} \mathrm{S}$; in the area of the San Guillermo Provincial Reserve. The abundances for the southern populations in this country would not be homogeneous, registering around 870 individuals in the Laguna Brava Provincial Reserve to 1,292 individuals in the San Guillermo Provincial Reserve (Baigún et al. 2008). The abundance for all of the Atacama region, in Chile, has been estimated between 120 (Glade \& 
Cunazza 1992) and 290 individuals, for a population north of the Negro Francisco lagoon (2730'S) (Galaz 1998).

The objective of this study is to clarify the presence of $V$. vicugna in the Atacama region and review the southernmost distribution limit in Chile, providing information of seasonal presence and the degree of association to community vegetation.

The field work was maked since January 2006 to January 2011 ten surveys (two observers; 820 hours) were carried out in the Vallenar mountain range, in the region of Atacama, Chile. Rounds were carried out in different seasons of the year (one in winter, five in summer, three in spring and one in autum) in order to characterise its seasonal presence. While surveying, the records considered the presence, association to the vegetal formation, number and group size of the observed vicuña, by age class (adults and off-springs).

The study area belongs to a sector of the Andes mountain range, between $28^{\circ} 30^{\prime}$ and $28^{\circ} 53^{\prime} \mathrm{S}$ and from 3,000 to 4,200 $\mathrm{m}$ a.s.l., the total surveyed area was of approximately $214 \mathrm{~km}^{2}$. From the point of view of its vegetation, the area is described as belonging to the high Andean Doña Ana steppe formation, which extends from the south of the region of Atacama to the north of the region of Coquimbo (Gajardo 1994) and its located in the Andean eco-geographical landscape which is characterised by a flora with important endemic elements of the Andes of Chile and Argentina, with predominance of winterly precipitations, mainly snow, the presence of an abrupt relief, very mountainous and the presence of a type of vegetation with the physiognomy of a high altitude desert landscape (Novoa et al. 2008).
During the surveys vicuña were seen between $28^{\circ} 33^{\prime} \mathrm{S}$ and $28^{\circ} 39^{\prime} \mathrm{S}$; being them absent in the sector of Valerianos $\left(28^{\circ} 53^{\prime} \mathrm{S} ; 70^{\circ} 02^{\prime} \mathrm{W}\right)$ and Conay $\left(28^{\circ} 57^{\prime} \mathrm{S} ; 70^{\circ} 06^{\prime} \mathrm{W}\right)$ south of the study area and in the sector of the Manflas river source, northeast of the area $\left(28^{\circ} 15^{\prime} \mathrm{S} ; 69^{\circ} 42^{\prime} \mathrm{W}\right)$. The records were registered in an altitudinal range of 3,950 to $4,100 \mathrm{~m}$ a.s.l.

The presence of vicuña occurred between the months of October and March; being absent during the winterly surveys, although during this season the effort was less due to the inaccessibility of the area in this season. The group sizes ranged from two to 16 individuals (Table 1). The totality of records, the vicuña were associated to the formations of Andean steppe, dominated by Adesmia subterrranea Clos and Pappostipa chrysophylla (E. Desv.), and Adesmia echinus C. Presl, A. subterranea and P. chrysophylla, present over the 3,900 $\mathrm{m}$ a.s.l.

The records obtained in the ten campaigns carried out in the Andes mountain range, northeast of the city of Vallenar, allows us to determine the existence of a population of vicuña further south of the limit of the distribution initially described in the field records by Glade \& Cunnazza (1992). Others author as Novoa \& Wheeler (1984), Wheeler (1995), Marin et al. (2007) also by Wheeler \& Laker (2009) establishing the southern boundary between $29^{\circ} \mathrm{S}$ and $29^{\circ} 30^{\prime} \mathrm{S}$, do not provide information regarding the field records at these latitudes and, seem to be supported on literature information. Only Molina (1782) mentions the vicuña dwelling in the Coquimbo mountain range, south of the study area, field data obtained from information of a third party. Thus, our field records constitute the most austral ones for the western slope of the Andes mountain range.

TABLE 1. Vicugna vicugna, Vicuña, records in the study area.

TABLA 1 Vicugna vicugna, Vicuña, registros en el área de estudio.

\begin{tabular}{|c|c|c|c|c|}
\hline $\begin{array}{c}\text { INDIVIDUALS }^{1} \\
\mathrm{~N}^{\circ}\end{array}$ & Date & Latitude (S) & LONGITUdE (W) & $\begin{array}{c}\text { Altitude } \\
\text { m a.s.l. }\end{array}$ \\
\hline 10 & 8 March 2006 & $28^{\circ} 35^{\prime} 53^{\prime \prime}$ & $69^{\circ} 64^{\prime} 89^{\prime \prime}$ & 4,100 \\
\hline 15 & 9 March 2006 & $28^{\circ} 35^{\prime} 54^{\prime \prime}$ & $69^{\circ} 64^{\prime} 90^{\prime \prime}$ & 4,030 \\
\hline 2 & 16 October 2006 & $28^{\circ} 35^{\prime} 24^{\prime \prime}$ & $69^{\circ} 54^{\prime} 25^{\prime \prime}$ & 3,978 \\
\hline 3 & 16 October 2006 & $28^{\circ} 34^{\prime} 96^{\prime \prime}$ & $69^{\circ} 55^{\prime} 56^{\prime \prime}$ & 3,874 \\
\hline 3 & 16 October 2006 & $28^{\circ} 39^{\prime} 00^{\prime \prime}$ & $69^{\circ} 54^{\prime} 00^{\prime \prime}$ & 3,787 \\
\hline 6 & 17 October 2006 & $28^{\circ} 35^{\prime} 45^{\prime \prime}$ & $69^{\circ} 66^{\prime} 29^{\prime \prime}$ & 4,057 \\
\hline 10 & 7 March 2009 & $28^{\circ} 35^{\prime} 53^{\prime \prime}$ & $69^{\circ} 64^{\prime} 89^{\prime \prime}$ & 4,067 \\
\hline 6 & 7 March 2009 & $28^{\circ} 33^{\prime} 60^{\prime \prime}$ & $69^{\circ} 61^{\prime} 97^{\prime \prime}$ & 3,957 \\
\hline 6 & 29 September 2010 & $28^{\circ} 33^{\prime} 57^{\prime \prime}$ & $69^{\circ} 61^{\prime} 80^{\prime \prime}$ & 4,057 \\
\hline 3 & 23 October 2010 & $28^{\circ} 35^{\prime} 20^{\prime \prime}$ & $69^{\circ} 54^{\prime} 05^{\prime \prime}$ & 3,980 \\
\hline
\end{tabular}

${ }^{1}$ Maximum number recorded in the study area (16 individuals) 7 March 2009. 


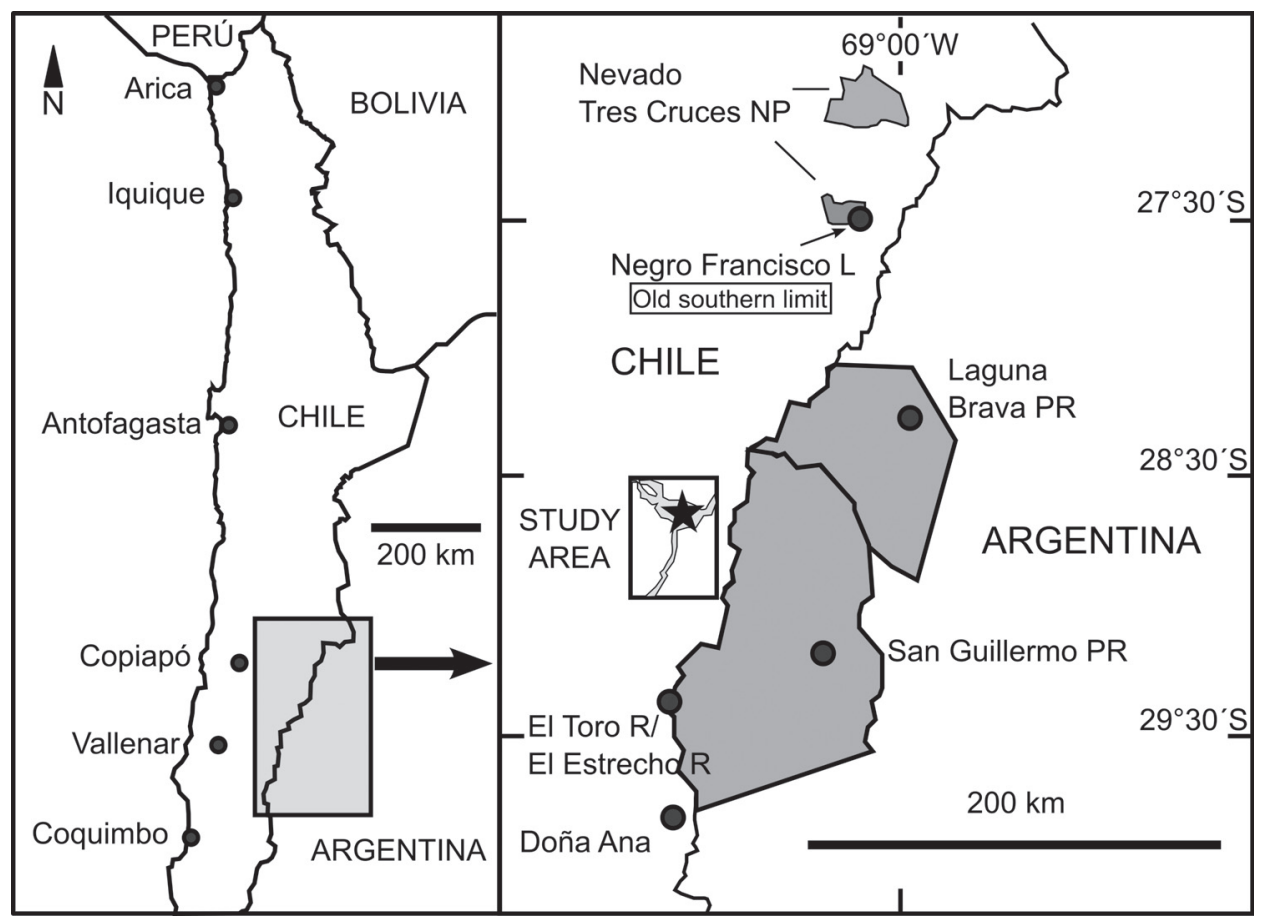

Figure 1: Study area and locations in the southern distribution limit of the vicuña, Vicugna vicugna. Black Star: New Southernmost limit in Chile, NP: National park, PR: Provicial reserve, L: Lagoon, R: River

Figura 1: Área de estudio y localidades en el límite de distribución sur de la vicuña Vicugna vicugna. Estrella Negra: nuevo límite sur en Chile, NP: Parque Nacional, PR: Reserva Provincial, L: Laguna, R: Río.

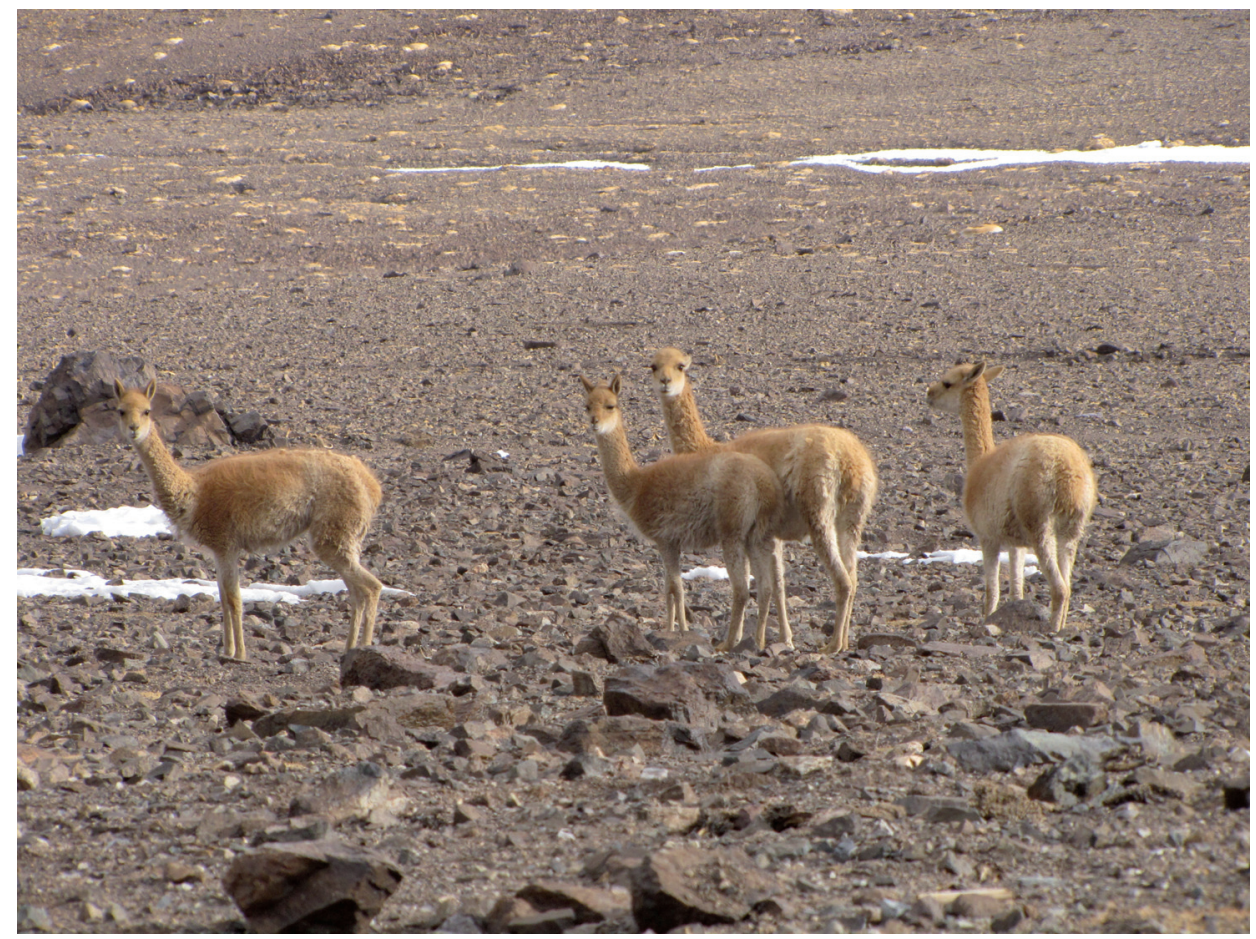

FIGURE 2. Individuals of Vicugna vicugna in the study area.

FIGURA 2. Individuos de Vicugna vicugna en el área de estudio. 


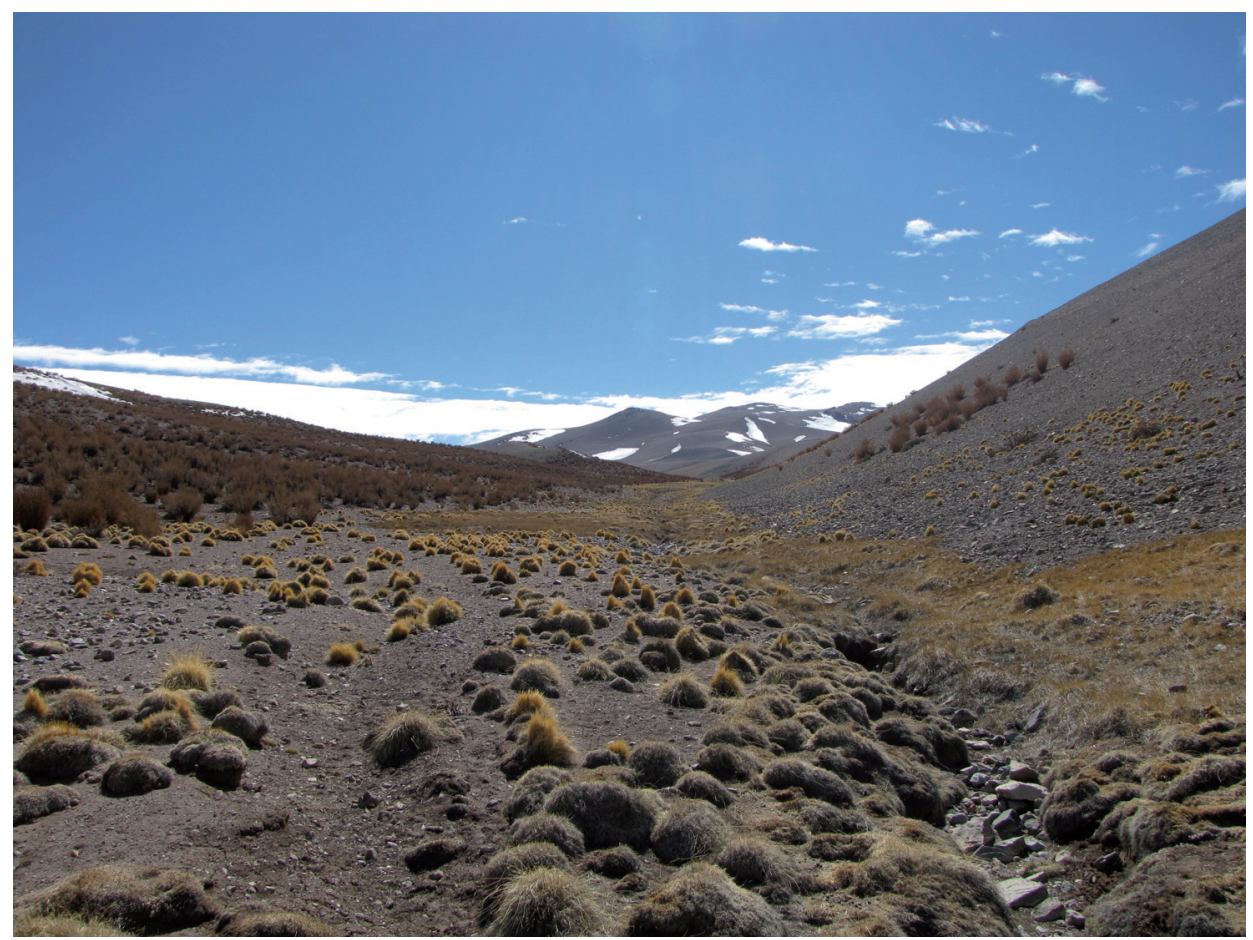

FIGURE 3. Vegetation in the study area.

Figura 3. Vegetación en el área de estudio.

On the western slope of the Andes, the populations closer to that described in this work, are located $140 \mathrm{~km}$ further north at the Negro Francisco lagoon, Copiapo mountain range $\left(27^{\circ} 30^{\prime} \mathrm{S}\right)$. On the eastern slope of the Andes mountain range, at about $110 \mathrm{~km}$ northeast the population of the Laguna Brava Provincial Reserve (28 $20^{\prime} \mathrm{S}$; $\left.68^{\circ} 50^{\prime} \mathrm{W}\right)$, Province of La Rioja, exists; and another one at about $80 \mathrm{~km}$. southeast of the study area, in the San Guillermo Provincial Reserve $\left(29^{\circ} 30^{\prime} \mathrm{S} ; 6^{\circ} 30^{\prime} \mathrm{W}\right)$, Province of San Juan, Argentina. It is probable that this population may be associated with the existing ones in the argentinian sector, whose core would be in the San Guillermo Provincial Reserve (Figure 1). Though the relationships among the population of vicuña of both slopes in this area of their distribution has not been studied and the existence of local displacements or migrations is unknown.

Although it is possible to find other groups of vicuña south from the study area this possibility seems low; at least, at the Doña Ana mountain range $\left(30^{\circ} 00^{\prime} \mathrm{S}\right)$ they would not be present (Cortes et al. 1995), as well they were not registered in the sector of the basin of the Turbio river, Province of San Juan, Argentina, and in the basin head of the Del Estrecho river, tributary of the Huasco river, Region de Atacama $\left(29^{\circ} 19^{\prime} \mathrm{S}\right)$ (Vilina, unpublished data ).

In Argentina, between $26^{\circ} 30^{\prime} \mathrm{S}$ and $28^{\circ} 20^{\prime} \mathrm{S}$, neighboring the border with Chile, here would exist a small vicuña population, lesser than 100 individuals (Laker et al. 2006), situation that matches with the records in Chile, where 120 and 290 individuals would have been registered north of the Negro Francisco lagoon $\left(27^{\circ} 30^{\prime}\right.$ S) (Glade \& Cunnazza 1992; Galaz 1998). The records of vicuña in the study area did not exceed 16 individuals as a maximum number, this small population would indeed be closer to other populations of Argentina, than those described at northern Chile; although the information of the sector within the $27^{\circ} 30^{\prime} \mathrm{S}$, at their latter southernmost distribution limit and the $28^{\circ} 30^{\prime} \mathrm{S}$, north of the study area it is scant and deficient. There would be a seasonal shift in the abundance of vicuña, what could go along with local movements, with some individuals abandoning the area in the cold and less productive months, yet it is necessary to study with a greater effort this pattern.

Until now it had been quoted that the vicuña associated to the vegetation communities included formations of the Altiplano (sensu Cabrera \& Willink 1973). In this work we reported the presence of vicuña in the high andean province (sensu Cabrera \& Willink 1973), particularly in the Huasco river high andean basin, in grasslands and high steppe above the $4,000 \mathrm{~m}$ a.s.l. Considering the available literature, these record obtained between the $28^{\circ} 33^{\prime} \mathrm{S}$ and the $28^{\circ} 39^{\prime} \mathrm{S}$, allows to establish a new southern distribution limit for the vicuña in Chile, this time with field data. 


\section{ACKNOWLEGDEMENTS}

To Sebastian Tellier and Javiera Delanoy for the information about the vegetation. To Eduardo Valenzuela, Denisse Placencia, Paola Sáez, Claudia Molina, Claudio Seguel, Alicia Cruz and Solange Gantenbein. This study was financed by El Morro Mining Company and backed by Knight Piésold S.A., Chile.

\section{BIBLIOGRAPHY}

Baigún R.J., Bolkovic, M.L., Aued, M.B., Li Puma, M.C. \& Scandalo, R.P. 2008. Manejo fauna silvestre en la Argentina, primer censo nacional camélidos silvestres al norte del río Colorado. Dirección Fauna Silvestre, Secretaría Ambiente y Desarrollo Sustentable. Buenos Aires, Argentina. 104 pp.

Cabrera, A. \& Willink, A.1973. Biogeografía América Latina. Programa Regional Desarrollo Científico y Tecnológico, OEA, Washington. Serie Biología. Monografía 13. 120 pp.

CAJAL, J. 1989. Uso del hábitat por vicuña y guanaco en la Reserva San Guillermo, Argentina. Vida Silvestre Neotropical 2:21-31.

Cajal, J. \& López, N. 1987. El Puma como depredador de camélidos silvestres en la Reserva Provincial San Guillermo. Revista Chilena de Historia Natural 60:87-91.

Cajal, J. \& Puig, S. 1992. Argentina. In: South American Camelids: an action plan for their conservation. IUCN (International Union for Conservation Nat. and Nat. Resour.) South American Camelids (Ed. Torres, H.), pp. 5-9. Spec. Group. Gland, Switzerland.

Cortes, A., Torres-Mura, J.C., Contreras, L. \& Pino, C. 1995. Fauna de Vertebrados de los Andes Coquimbo: Cordillera de Doña Ana. Ediciones Universidad La Serena, La Serena, Chile. 96 pp.

FrankLIN, W.L. 1982. Biology, ecology, and relationship to man of the South American camelids., In: Mammalian Biology in South America (Eds. Mares, M.A. \& Genoways, H.H.), pp. 457-489. Pymatuning Symposia in Ecology No. 6, University of Pittsburgh, Linesville, Pennsylvania.

Gajardo, R. 1994. La Vegetación Natural Chile. Clasificación y Distribución Geográfica. Edit. Universitaria, Santiago. 165 pp.

Galaz, J.L. 1998. El manejo de la vicuña (Vicugna vicugna Lesson, 1842 ) en Chile. In: La conservación la fauna nativa en Chile: logros y perspectivas (Ed. Valverde, V.), pp. 5-18. Corporación Nacional Forestal, Ministerio Agricultura Chile, Santiago, Chile.

Galaz, J.L. 2005. Antecedentes Generales. In: Técnicas para el Manejo Productivo la Vicuña (Vicugna vicugna Molina, 1782) (Eds. Galaz, J.L. \& González, G.), pp. 19-37. Corporación Nacional Forestal - Fundación para la innovación agraria (CoNaF - Fia). Santiago, Chile.

Glade, A. \& Cunazza, C. 1992. Chile. In: South American Camelids: an action plan for their conservation. IUCN (International Union for Conservation Nat. and Nat.
Resour.) South American Camelids. (Ed. Torres, H.), pp. 14-18. Spec. Group. Gland, Switzerland.

González, G., Torres-Mura, J.C. \& Muños-Pedreros, A. 2000. Orden Artiodactyla. In: Mamíferos Chile (Eds. MuñozPedreros, A. \& Yáñez, J.), pp. 189-206. CEA Ediciones.

González, G., Torres-Mura, J.C. \& Muños-Pedreros, A. 2009. Orden Artiodactyla., In: Mamíferos Chile (Eds. MuñozPedreros, A. \& Yáñez, J.), pp. 231-250. Segunda Edición. CEA Ediciones.

Iriarte, A. 2008. Mamíferos Chile. Lynx Edicions. Barcelona, España. $420 \mathrm{pp}$.

Laker, J, Baldo, J., Arzamendia, Y. \& Yacobaccio, H. 2006. La vicuña en los Andes. In: Investigación, conservación y manejo vicuña (Ed. Vilá, B.), pp. 37-50. Proyecto MACSArgentina, Buenos Aires.

LuCherini, M. \& Birochio, D.E. 1997. Lack of Agression and Avoidance Between Vicuña and Guanaco Herds Grazing in the Same Andean Habitats. Studies of Neotropical Fauna \& Environment 32: 7275.

Marín, J.C., Casey, C.S., Kadwell, M., Yaya, K., Hoces, D., Olazabal, J., Rosadio, R., Rodriguez, J., Spotorno, A., Bruford, M.W. \& WheELER, J.C. 2007. Mitochondrial phylogeography and demographic history of the Vicuña: implications for conservation. Heredity 99:70-80.

Molina, I. 1782. Saggio sulla storia naturale del Chili. Bologna Vol $8.368 \mathrm{pp}$.

NovoA, C. \& WheEler, J.C. 1984. Llama and alpaca. In: Evolution of domesticated animals (Mason I, ed.), pp. 116-128. Longman, London.

NovoA, J.E., Tracol, Y. \& LóPEZ, D. 2008. Paisajes Eco-geográficos la Región Atacama. In: Libro Rojo la Flora Nativa y los Sitios Prioritarios para su Conservación: Región Atacama (Eds. Squeo, F.A., Arancio, G. \& Gutiérrez, J.R.), pp. 1324. Ediciones Universidad La Serena, La Serena.

OsGood, W.H. 1943. The mammals of Chile. Field Museum of Natural History, Zoology Series 30:1-268.

TorRes, H. 1992. South American Camelids: an action plan for their conservation. IUCN (International Union for Conservation Nat. and Nat. Resour.) South American Camelids. Spec. Group. Gland, Switzerland. 58 pp.

WheEler, J.C. 1991. Origen, evolución and status actual. In: Avances and perspectivas del conocimiento de los los camélidos sudamericanos (Ed. Fernández-Baca, S.), pp. 11-48. Oficina Regional la FAO para América Latina and el Caribe, Santiago.

WheELER, J. 1995. Evolution and present situation of the South American Camelidae. Biological Journal of the Linnean Society 54:271-295.

WheEler, J. \& LAKER, J. 2009. The Vicuña in the Andean Altiplano. In: The vicuna: the theory and practice of community based wildlife management (Ed. Gordon, I.J.), pp. 21-34. Springer. Springer Verlag, Berlin, Germany.

Weinstock, J., Shapiro, B., Prieto, A., Marín, J.C., GonzÁlez, B.A., Gilbert, M.T. \& Willerslev. 2009. The Late Pleistocene distribution of vicuña (Vicugna vicugna) and the "extinction" of the gracile llama ("Lama gracilis"): new molecular data. Quaternary Science Reviews 28:1369-1373.

Recibido: 27.05 .14

Aceptado: 02.10.15 